\title{
Editorial
}

\section{Oncogenic Processes}

\author{
Rita de Cassia Stocco, ${ }^{1}$ Franco Peppino Roperto, ${ }^{2}$ Lubna Nasir, ${ }^{3}$ and Marcelo Palma Sircili ${ }^{1}$ \\ ${ }^{1}$ Laboratório de Genética, Instituto Butantan, Secretaria de Estado da Saúde, Avenida Vital Brasil, 1500 Butantã, \\ 05503-900 São Paulo, SP, Brazil \\ ${ }^{2}$ Department of Biology, Naples University Federico II, Via Mezzocannone 16, 80134 Naples, Italy \\ ${ }^{3}$ Institute of Infection, Immunity and Inflammation, College of Medical, Veterinary and Life Sciences, \\ MRC-University of Glasgow Centre for Virus Research, Bearsden Road, Glasgow G61 1QH, UK \\ Correspondence should be addressed to Rita de Cassia Stocco; ritastocco@butantan.gov.br
}

Received 13 November 2013; Accepted 13 November 2013; Published 16 January 2014

Copyright (C) 2014 Rita de Cassia Stocco et al. This is an open access article distributed under the Creative Commons Attribution License, which permits unrestricted use, distribution, and reproduction in any medium, provided the original work is properly cited.

The relevance of cancer to human health is extremely high and the efforts to understand and control the processes related to the oncogenic modifications that take place in cells have increased, dramatically, in the past few decades [1-3]. The special issue presents a broad view of this subject.

Actually, oncogenic process was discussed by the authors that contributed to the Special Issue and have clearly demonstrated that this process involves the action of different agents on the cell [1,4-7].

The major contribution achieved was the diversity of the approaches; the studies have brought together important aspects of cell transformation and also concerted efforts directed towards therapeutic procedures. The editors hope that this issue can help partially to the complex problems involved in these processes.

When we consider the etiology of tumor cells, papillomaviruses come immediately to mind: the relevance of HPVs (human papillomavirus) in female cervical cancer has obtained the priority in the virus-cancer relationship discussion [1, 2, 4, 8-10]. Its incidence turns it in a worldwide human health problem. In this volume, we have the opportunity to study persistence or clearance in HPV infection in order to allow the identification of risk groups, cofactors, and strategies for prevention of cervical cancer. At the same time, the issue presents results of research on less common HPV types that might be involved in cervical lesions and that some of these variants can be found in B-cell and T-cell epitopes [11-15].

Animal models have played a contributions to the understanding of oncogenic processes $[5,10,16-26]$. One of them deserves special attention: Bovine papillomavirus. This group of viruses is directly related to serious clinical consequences in bovine, namely papillomatosis, esophagus tract carcinoma, and urinary bladder carcinoma leading to animal death and in equids, sarcoid tumours that presents similar results $[10$, 18 , 27]. These diseases lead to dramatic economic hazards. BPV animal model has been studied in several aspects, as illustrated in the different papers included in this issue, since many aspects of bovine papillomavirus infection and pathogenesis remain still to be clarified [28]. The oncogenesis process is mainly associated with different viral oncoprotein expressions, which are involved in cell transformation $[7,12$, $19,29]$. The accuracy of diagnostic processes and the distribution of the different viral types [14, 26, 30-32] indicate which types and variants deserve the special attention $[8,9,25$, $33,34]$. The expression and characterization of recombinant viral oncoproteins are required to obtain biotechnological products as antibodies and potential vaccines $[9,15,35-$ 37]. Further studies show association of oncoproteins and cell compounds, as PDGF $\beta$ receptor and their actions in transformation of epithelial cell to mesenchymal cell as well as epithelial carcinogenesis of the urinary bladder [17, 33, 38]. The oncoproteins also act on host cell chromatin, in epithelial and blood cells [18, 23, 27, 39]. The virus DNA sequences have been described in semen, urine, and other non conventional host cells [10, 17, 20, 21, 23, 29, 33]. However, the initial event of the malign process remains not determined.

Chromosome aberrations can be detected in very diverse neoplastic process; bovine leukemia virus (BLV) was investigated and reported presenting chromosome breakage in 
lymphocytes [16] and in the central nervous system (CNS) of cattle with neurological syndrome. While in papillomavirus, the chromosome aberrations occur at random, in tumor cells, virus sequences can be integrated in specific sites or the malign process can be related to products as in leukemia, fusion protein RUNX1/ETO that is generated by the chromosomal translocation $\mathrm{t}(8 ; 21)[40-43]$.

The oncogenic process can have another trigger, not specifically chromatin lesions. Gap junctions are communicating junctions which are important for tissue homeostasis, and their disruption is involved in carcinogenic process; connexin 43 deficiency is a clear example [44-46]. Cell surface proteins are related as targets for the beginning of the cancer development and consequently for cancer therapy or diagnosis [47-50]. These aspects have been well discussed in oncogenic processes; the expression of different genes in breast tumors, alternative TrkAIII splice variant expressed by advanced stage human neuroblastomas (NBs).

In a final evaluation, the papers pointed very clearly the complexity of the events leading to cancer. This complexity, obviously, reaches the diagnosis and therapy possibilities. In the ongoing studies, molecules are being analyzed to create ways to interfere with the tumor cell. In the special issue, viral oncoproteins were also considered through bioinformatics approach. The volume includes a detailed review of a purified peptide from South American rattle snake, a venom chemical crotamine [51-53] that is being discussed as a vector to reach the malign cell.

Our major aim in organizing this volume was to emphasize that the first step in oncogenic process is until now under discussion and therefore is the key for prophylaxis, diagnosis, and therapy. An attractive possibility is that the key remains in any alteration in the natural history of a cell; any cell, as any organism, has beginning, development, ageing, and death. When this route is modified, due to a large range of events, this cell can follow a different way and compete with its similar tissue cells, and, when this occurs in advantage, tumor cells win and the cancer happens.

The special issue (oncogenic processes) is celebrating the 80th birthday of Prof Dr. Willy Beçak, former Director of Instituto Butantan and remarkable researcher in cancer etiology studies and in the developing of vaccines.

We hope that this special issue (oncogenic processes) can contribute to this scientific area, bringing to readers accurate data and important discussions about this subject; but, mainly, we hope that this special issue will initiate new discussions relating to the elucidation of mechanisms and oncogenic process.

Rita de Cassia Stocco
Franco Peppino Roperto
Lubna Nasir
Marcelo Palma Sircili

\section{References}

[1] H. Zur Hausen, "Papillomaviruses and cancer: from basic studies to clinical application," Nature Reviews Cancer, vol. 2, no. 5, pp. 342-350, 2002.
[2] M. S. Campo, "Papillomavirus and disease in humans and animals," Veterinary and Comparative Oncology, vol. 1, pp. 3-14, 2003.

[3] J. N. Eble, G. Sauter, J. I. Epstein, and I. A. Sesterhenn, Pathology and Genetics of Tumours of the Urinary System and Male Genital Organs, IARC WHO Classification of Tumours, IARC Press, Lyon, France, 2004.

[4] X. Castellsagué and N. Muñoz, "Chapter 3: cofactors in human papillomavirus carcinogenesis-role of parity, oral contraceptives, and tobacco smoking," Journal of the National Cancer Institute. Monographs, no. 31, pp. 20-28, 2003.

[5] M. S. Campo, B. W. O’Neil, R. J. Barron, and W. F. H. Jarrett, "Experimental reproduction of the papilloma-carcinoma complex of the alimentary canal in cattle," Carcinogenesis, vol. 15, no. 8, pp. 1597-1601, 1994.

[6] M. S. Campo, W. F. H. Jarrett, R. Barron, B. W. O'Neil, and K. T. Smith, "Association of bovine papillomavirus type 2 and bracken fern with bladder cancer in cattle," Cancer Research, vol. 52, no. 24, pp. 6898-6904, 1992.

[7] G. Borzacchiello, G. Lovane, M. L. Marcante et al., "Presence of bovine papillomavirus type 2 DNA and expression of the viral oncoprotein E5 in naturally occurring urinary bladder tumours in cows," The Journal of General Virology, vol. 84, no. 11, pp. 2921-2926, 2003.

[8] P. M. Miranda, B. C. Pitol, M. S. Moran et al., "Human papillomavirus infection in Brazilian women with normal cervical cytology," Genetics and Molecular Research, vol. 11, no. 2, pp. 1752-1761, 2012.

[9] H.-U. Bernard, S.-Y. Chan, M. M. Manos et al., "Identification and assessment of known and novel human papillomaviruses by polymerase chain reaction amplification, restriction fragment length polymorphisms, nucleotide sequence, and phylogenetic algorithms," Journal of Infectious Diseases, vol. 170, no. 5, pp. 1077-1085, 1994.

[10] L. Nasir and M. S. Campo, "Bovine papillomaviruses: their role in the aetiology of cutaneous tumours of bovids and equids," Veterinary Dermatology, vol. 19, no. 5, pp. 243-254, 2008.

[11] D. G. DeNardo, M. Johansson, and L. M. Coussens, "Immune cells as mediators of solid tumor metastasis," Cancer and Metastasis Reviews, vol. 27, no. 1, pp. 11-18, 2008.

[12] B. Marchetti, G. H. Ashrafi, E. Tsirimonaki, P. M. O’Brien, and M. S. Campo, "The bovine papillomavirus oncoprotein E5 retains MHC class I molecules in the Golgi apparatus and prevents their transport to the cell surface," Oncogene, vol. 21, no. 51, pp. 7808-7816, 2002.

[13] H. Zur Hausen, "Papillomavirus infections-a major cause of human cancers," Biochimica et Biophysica Acta, vol. 1288, no. 2, pp. F55-F78, 1996.

[14] G. Cornut, S. Gagnon, C. Hankins et al., "Polymorphism of the capsid L1 gene of human papillomavirus types 31, 33, and 35," Journal of Medical Virology, vol. 82, no. 7, pp. 1168-1178, 2010.

[15] T. A. Hall, "BioEdit: a user-friendly biological sequence alignment editor and analysis program for Windows 95/98/NT," Nucleic Acids Symposium Series, vol. 1, pp. 95-98, 1999.

[16] N. H. Castro, J. Walter, R. C. dos Santos et al., "Cytogenetic study of cattle affected by persistent lymphocytosis," Zentralblatt für Veterinarmedizin A, vol. 35, no. 5, pp. 380-384, 1988.

[17] S. Roperto, G. Borzacchiello, R. Brun et al., "A review of bovine urothelial tumours and tumour-like lesions of the urinary bladder," Journal of Comparative Pathology, vol. 142, no. 2-3, pp. 95-108, 2010. 
[18] R. C. Stocco dos Santos, C. J. Lindsey, O. P. Ferraz et al., "Bovine papillomavirus transmission and chromosomal aberrations: an experimental model," The Journal of General Virology, vol. 79, no. 9, pp. 2127-2135, 1998.

[19] G. Borzacchiello, V. Russo, C. Spoleto et al., "Bovine papillomavirus type-2 DNA and expression of E5 and E7 oncoproteins in vascular tumours of the urinary bladder in cattle," Cancer Letters, vol. 250, no. 1, pp. 82-91, 2007.

[20] C. de Carvalho, A. C. de Freitas, O. Brunner et al., "Bovine papillomavirus type 2 in reproductive tract and gametes of slaughtered bovine females," Brazilian Journal of Microbiology, vol. 34, no. 1, pp. 82-84, 2003.

[21] C. J. Lindsey, M. E. Almeida, C. F. Vicari et al., "Bovine papillomavirus DNA in milk, blood, urine, semen, and spermatozoa of bovine papillomavirus-infected animals," Genetics and Molecular Research, vol. 8, no. 1, pp. 310-318, 2009.

[22] S. R. C. Campos, C. Trindade, O. P. Ferraz et al., "Can established cultured papilloma cells harbor bovine papillomavirus?" Genetics and Molecular Research, vol. 7, no. 4, pp. 1119-1126, 2008.

[23] A. Yaguiu, M. L. Z. Dagli, E. H. Birgel Jr. et al., "Simultaneous presence of bovine papillomavirus and bovine leukemia virus in different bovine tissues: in situ hybridization and cytogenetic analysis," Genetics and Molecular Research, vol. 7, no. 2, pp. 487497, 2008.

[24] V. Turusov and U. Mohr, Pathology of Tumours in Laboratory Animals: Tumors of the Mouse, IARC Scientific Publication (WHO), Lyon, France, 2nd edition, 1994.

[25] S. Roperto, R. Brun, F. Paolini et al., "Detection of bovine papillomavirus type 2 in the peripheral blood of cattle with urinary bladder tumours: possible biological role," The Journal of General Virology, vol. 89, no. 12, pp. 3027-3033, 2008.

[26] N. Diniz, T. C. Melo, J. F. Santos et al., "Simultaneous presence of bovine papillomavirus in blood and in short-term lymphocyte cultures from dairy cattle in Pernambuco, Brazil," Genetics and Molecular Research, vol. 8, no. 4, pp. 1474-1480, 2009.

[27] J. You, "Papillomavirus interaction with cellular chromatin," Biochimica et Biophysica Acta, vol. 1799, no. 3-4, pp. 192-199, 2010.

[28] T. Haga, J. Dong, W. Zhu, and R. D. Burk, “The many unknown aspects of bovine papillomavirus diversity, infection and pathogenesis," Veterinary Journal, vol. 197, pp. 122-123, 2013.

[29] S. Roperto, S. Comazzi, E. Ciusani et al., "PBMCS are additional sites of productive infection of bovine papillomavirus type 2," The Journal of General Virology, vol. 92, no. 8, pp. 1787-1794, 2011.

[30] D. Geraets, L. Alemany, N. Guimera et al., "Detection of rare and possibly carcinogenic human papillomavirus genotypes as single infections in invasive cervical cancer," The Journal of Pathology, 2012.

[31] T. Ogawa, Y. Tomita, M. Okada, and H. Shirasawa, "Complete genome and phylogenetic position of bovine papillomavirus type 7," The Journal of General Virology, vol. 88, no. 7, pp. 19341938, 2007.

[32] T. Vincze, J. Posfai, and R. J. Roberts, "NEBcutter: a program to cleave DNA with restriction enzymes," Nucleic Acids Research, vol. 31, no. 13, pp. 3688-3691, 2003.

[33] S. Roperto, V. Russo, A. Ozkul et al., "Bovine papillomavirus type 2 infects the urinary bladder of water buffalo (Bubalus bubalis) and plays a crucial role in bubaline urothelial carcinogenesis," The Journal of General Virology, vol. 94, pp. 403-408, 2013.
[34] H.-U. Bernard, R. D. Burk, Z. Chen, K. van Doorslaer, H. Z. Hausen, and E.-M. de Villiers, "Classification of papillomaviruses (PVs) based on 189 PV types and proposal of taxonomic amendments," Virology, vol. 401, no. 1, pp. 70-79, 2010.

[35] Y. Modis, B. L. Trus, and S. C. Harrison, "Atomic model of the papillomavirus capsid," The EMBO Journal, vol. 21, no. 18, pp. 4754-4762, 2002.

[36] Y. Liu and J. D. Baleja, "Structure and function of the papillomavirus E6 protein and its interacting proteins," Frontiers in Bioscience, vol. 13, no. 1, pp. 121-134, 2008.

[37] Y. Modis, B. L. Trus, and S. C. Harrison, "Atomic model of the papillomavirus capsid," The EMBO Journal, vol. 21, no. 18, pp. 4754-4762, 2002.

[38] F. Tavora, O. N. Kryvenko, and J. I. Epstein, "Mesenchymal tumours of the bladder and prostate: an update," Pathology, vol. 45, pp. 104-115, 2013.

[39] T. C. Melo, N. Diniz, S. R. C. Campos et al., "Cytogenetic studies in peripheral blood of bovines afflicted by papillomatosis," Veterinary and Comparative Oncology, vol. 9, no. 4, pp. 269-274, 2011.

[40] K. Döhner and H. Döhner, "Molecular characterization of acute myeloid leukemia," Haematologica, vol. 93, no. 7, pp. 976-982, 2008.

[41] F. Rosenbauer and D. G. Tenen, "Transcription factors in myeloid development: balancing differentiation with transformation," Nature Reviews Immunology, vol. 7, no. 2, pp. 105-117, 2007.

[42] A. T. Look, "Oncogenic transcription factors in the human acute leukemias," Science, vol. 278, no. 5340, pp. 1059-1064, 1997.

[43] J. R. McWhirter, D. L. Galasso, and J. Y. J. Wang, "A coiled-coil oligomerization domain of $\mathrm{Bcr}$ is essential for the transforming function of Bcr-Abl oncoproteins," Molecular and Cellular Biology, vol. 13, no. 12, pp. 7587-7595, 1993.

[44] M. Mesnil, "Connexins and cancer," Biology of the Cell, vol. 94, no. 7-8, pp. 493-500, 2002.

[45] M. L. Z. Dagli and F. J. Hernandez-Blazquez, "Roles of gap junctions and connexins in non-neoplastic pathological processes in which cell proliferation is involved," The Journal of Membrane Biology, vol. 218, no. 1-3, pp. 79-91, 2007.

[46] B. Cogliati, T. C. da silva, T. P. A. Aloia et al., "Morphological and molecular pathology of CCL4-induced hepatic fibrosis in connexin43-deficient mice," Microscopy Research and Technique, vol. 74, no. 5, pp. 421-429, 2011.

[47] C. M. Perou, T. Sørile, M. B. Eisen et al., "Molecular portraits of human breast tumours," Nature, vol. 406, no. 6797, pp. 747-752, 2000.

[48] L. Harris, H. Fritsche, R. Mennel et al., "American Society of Clinical Oncology 2007 update of recommendations for the use of tumor markers in breast cancer," Journal of Clinical Oncology, vol. 25, no. 33, pp. 5287-5312, 2007.

[49] L. J. van't Veer, H. Dai, M. J. van de Vijver et al., "Gene expression profiling predicts clinical outcome of breast cancer," Nature, vol. 415, no. 6871, pp. 530-536, 2002.

[50] J. P. C. da Cunha, P. A. F. Galante, J. E. de Souza et al., "Bioinformatics construction of the human cell surfaceome," Proceedings of the National Academy of Sciences of the United States of America, vol. 106, no. 39, pp. 16752-16757, 2009.

[51] G. Nicastro, L. Franzoni, C. de Chiara, A. C. Mancin, J. R. Giglio, and A. Spisni, "Solution structure of crotamine, a $\mathrm{Na}^{+}$channel affecting toxin from Crotalus durissus terrificus venom," European Journal of Biochemistry, vol. 270, no. 9, pp. 1969-1979, 2003. 
[52] C. Plank, B. Oberhauser, K. Mechtler, C. Koch, and E. Wagner, "The influence of endosome-disruptive peptides on gene transfer using synthetic virus-like gene transfer systems," Journal of Biological Chemistry, vol. 269, no. 17, pp. 12918-12924, 1994.

[53] M. Zorko and Ü. Langel, "Cell-penetrating peptides: mechanism and kinetics of cargo delivery," Advanced Drug Delivery Reviews, vol. 57, no. 4, pp. 529-545, 2005. 


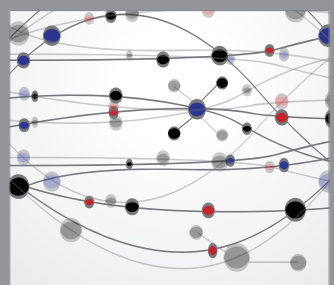

The Scientific World Journal
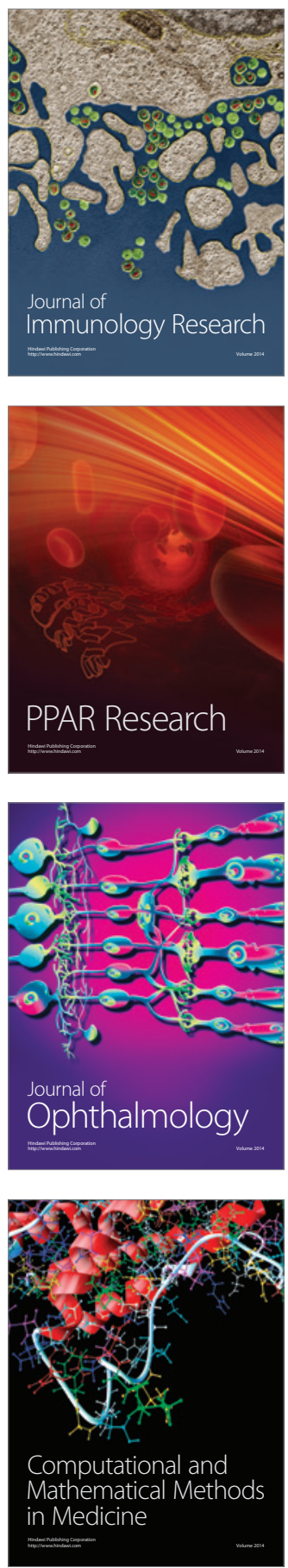

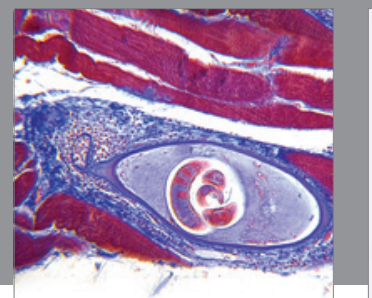

Gastroenterology

Research and Practice
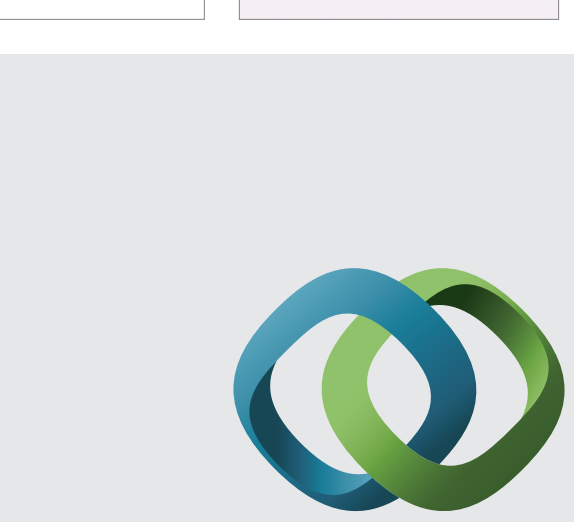

\section{Hindawi}

Submit your manuscripts at

http://www.hindawi.com
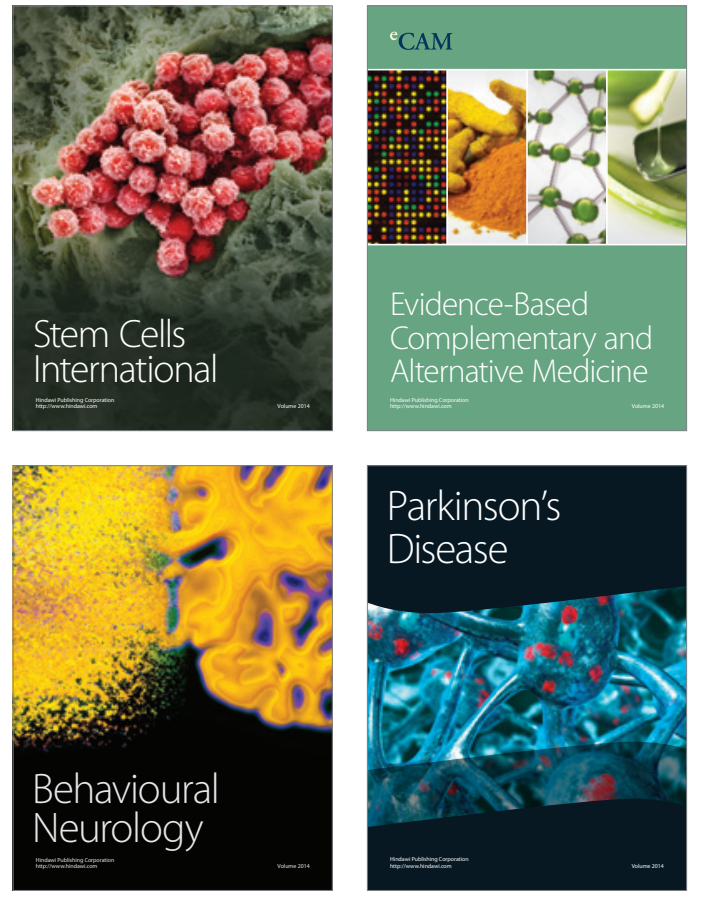
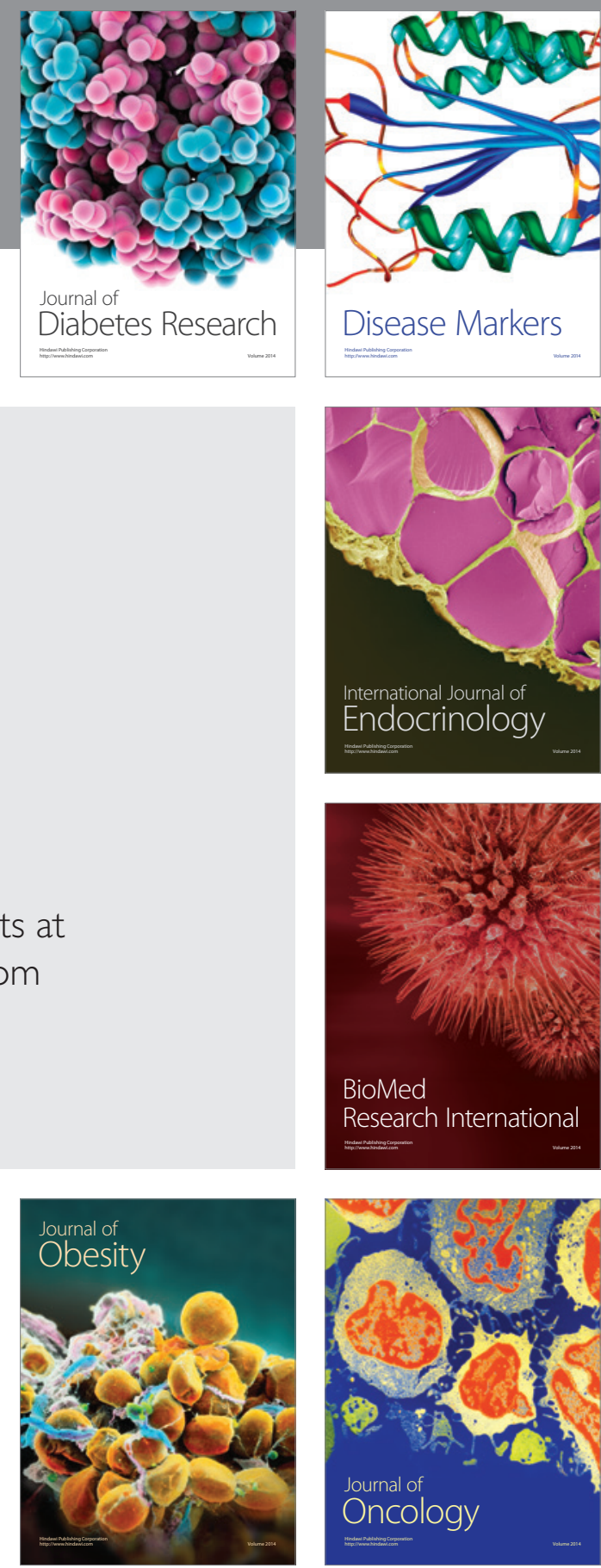

Disease Markers
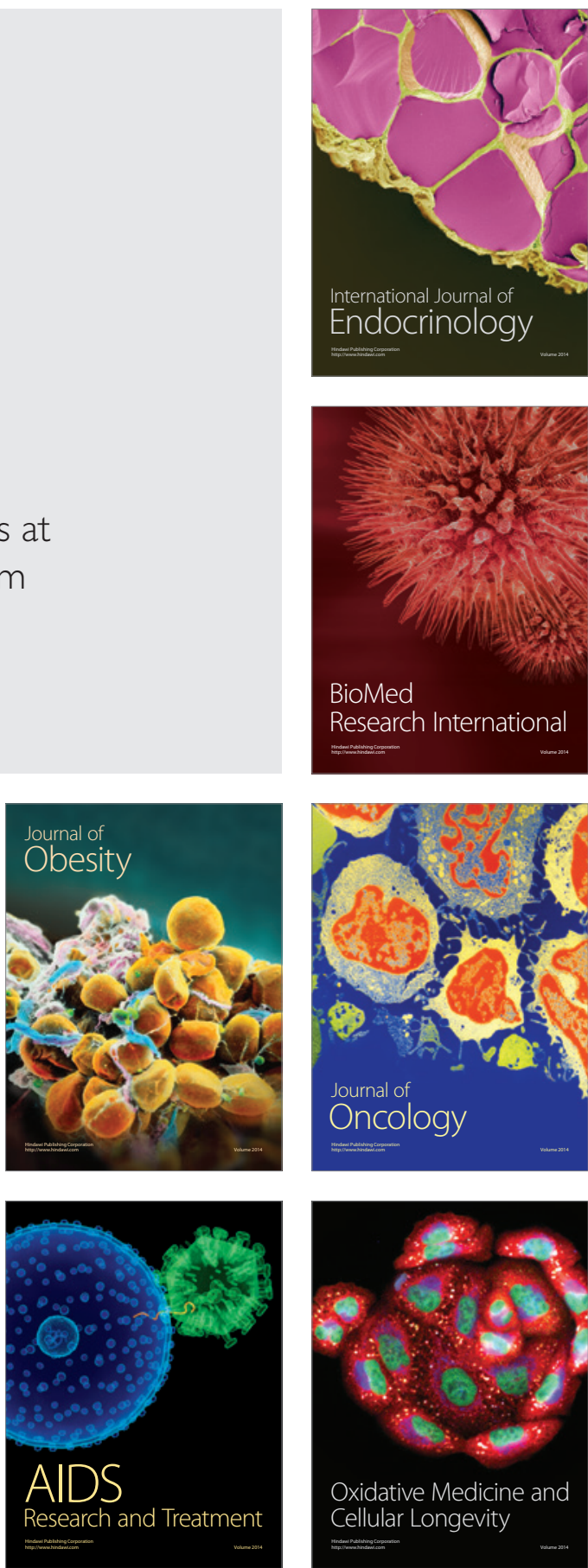